\title{
The Role of Parents in Engaging Early Childhood to Implement 3R (Reduce, Reuse, Recycle)
}

\author{
Faizatul Faridy ${ }^{1, *}$, Aulia Rohendi ${ }^{2}$ \\ 1,2 Universitas Islam Negeri Ar-Raniry Banda Aceh, Indonesia \\ *Corresponding author.Email: faizatul.faridy@ar-raniry.ac.id
}

\begin{abstract}
One of the environmental impacts due to population growth and diversity of activities is the increasing problem of waste. The form of participation expected from the community is a willingness to sort and reduce the waste that will be transported considering the impact of waste is not only damaging aesthetics, but also affects health and causes disasters. One of the things that can be done at home is to apply the $3 \mathrm{R}$ concept (Reuse, Reduce and Recycle) and teach it to children to get used to it from an early age. Besides being able to protect the environment, 3R habituation can foster children's naturalist intelligence. This research was conducted to analyse the role of parents in engaging early childhood to implement the $3 \mathrm{R}$ and to review its relationship with naturalistic intelligence in early childhood. This study uses a qualitative approach with a case study design. Data collection was carried out using observation sheets and in-depth interviews. The findings of this study are, first, parents' education and background play a major role in implementing 3R at home. Second, the 3R application has a very close relationship with the naturalist intelligence of children, because the application of $3 \mathrm{R}$ at home by involving children makes children love the environment and be responsible for nature. Third, parents involve children in implementing the 3R through habituation and giving direct examples in daily life. Fourth, the child gave a positive response with $3 R$. Fifth, the implementation of $3 R$ is still difficult to implement in Indonesia because of infrastructure limitations and a lack of understanding of the $3 \mathrm{R}$ concept in society.
\end{abstract}

Keywords: Naturalistic Intelligence, Early childhood, Parenting, $3 R$.

\section{INTRODUCTION}

As the population increases, the diversity of community and industrial activities, as well as the development of science, also increases environmental problems such as lack of clean water, increasing pollution, increasing waste and so on. One of the worrisome environmental impacts is the waste problem. In 2020, it is estimated that the amount of waste will reach 13,710 million tons [1]. The 3R concept (Reduce, Reuse, Recycle) has become a concept that is applied all over the world. The $3 \mathrm{R}$ concept, namely reduction, reuse, and recycling has been used as the basis for waste management in countries that have successfully managed their urban waste, such as Japan, Taiwan and South Korea. Reduction and recycling efforts have significantly reduced the amount of waste that must be transported to be managed [2].
In Indonesia, Law No. 18 regarding Waste Management has been in effect since 2008, however until now Indonesia still tends to use the collect-transportwaste paradigm. All waste is brought and processed in the Final Processing Site (FPS) without high attention to reducing waste at the source (users/consumers). Processing waste only at the FPS is not an optimal solution. Destruction of waste into the ground as carried out in FPS has many risks, one of which is soil pollution [3]. The aspects that affect solid waste management are regulatory, political and public policy, institutional, operational, financial, socio-cultural and community participation and public health and the environment. Regarding socio-cultural aspects and community participation, in developed countries, the forms and systems of technology that will be applied in a city usually go through the stages of gathering public opinion. The form of participation that is also expected from the community is a willingness to sort and reduce the waste 
that will be transported [3]. Public awareness and participation should also be increased with various efforts considering the impact of waste is not only damaging to aesthetics, but also affects health (accumulation of disease vectors, causing odors and dust, water pollution) and causing disasters (flooding due to clogged waterways). Plastic waste is also often found in the bodies of marine or land animals, which can injure them and can lead to death. The Ministry of Environment [4] noted that the average Indonesian population produces around 2.5 litres of waste per day or 625 million litres of the total population.

Based on this discussion, it is considered necessary to have awareness of the community in minimizing solid waste piles by implementing the $3 \mathrm{R}$. The $3 \mathrm{R}$ habit can be done by involving family members from an early age. The habit of $3 \mathrm{R}$ in early childhood is intended so that an environmental care attitude instilled from an early age will become the character of the child until adulthood so that the child becomes more sensitive to the condition of the surrounding environment including the natural environment in which he lives. This attitude is part of naturalistic intelligence.

The results of Ju \& Kim's study show that environmental education shows positive changes in children towards the environment [5]. Other research states that through intervention, early childhood can apply newly acquired knowledge about ecological concepts [6]. Most of the research that has been conducted has focused on the results of the introduction of protecting the environment in children from an early age and most of the research was carried out in schools, while this study was to see in depth how the role of parents in engaging early childhood to implement the $3 R$ at home. In addition, this study also looks at how it relates to naturalistic intelligence after children are involved in 3R activities.

\section{LITERATURE REVIEW}

Humans are required to have multiple intelligences in order to adapt to the environment in which they live. For example, social intelligence in order to socialize with the surrounding humans, or naturalistic intelligence in order to recognize patterns and changes in the environment so that they can adapt and survive.

Naturalistic intelligence is one of the 9 multiple intelligences. Naturalistic intelligence involves the ability to recognize the natural forms around us: flowers, trees, animals, and other fauna and flora [7]. It also includes sensitivity to other natural forms such as cloud formation and the geological features of the earth. Naturalistic intelligence is the ability to recognize, classify and describe the various kinds that exist in the environment. Naturalistic intelligence is related to the left hemisphere of the brain, which is the part that is sensitive to the recognition of shapes or patterns, the ability to distinguish and classify things. If children can easily mark patterns of natural objects, and remember natural objects around them, they can be said to have high naturalist intelligence.

The characteristics of children who have naturalistic intelligence are [8]:

a) Loves to observe, recognize, interact, and care about natural objects, plants or animals.

b) Enthusiastic about the natural environment and the human environment.

c) Enjoys growing plants, animals and the environment.

d) Likes to study an organism/life of flora and fauna.

e) Enjoy doing outdoor activities.

It can be concluded that naturalistic intelligence is the ability to recognize patterns, capture sensory perceptions through all of the five senses, and carry out the separation and classification of certain objects. The benefit of naturalistic intelligence is that children can learn about the nature around them and make them more sensitive to nature, because this earth does not only need academically intelligent humans but also humans who are intelligent in treating nature. Naturalistic intelligence in children can be developed by playing activities in the wild such as observing plants and living things or through habituation at home, one of which is the $3 \mathrm{R}$ habituation.

The application of $3 \mathrm{R}$ can be described as follows [9]:

a) Reduce: reducing here means reducing or simplifying the consumption of products that are bought, consumed and removed as quickly as possible. For example, reducing single-use plastic packaging (use reusable bags, instead), using products that will be reusable (such as refillable drinking bottles), buying large packaged drinks instead of small packages, etc. Apart from waste, the reduce concept can also be used for water and energy use.

b) Reuse: The habit of reusing helps to extend product life. Before throwing something away and replacing it with something new, you can find a way to fix it, or give it a new use. For example, using empty glass containers as vases or condiments, using organic waste as compost, using fruit and vegetable washing water to water plants, etc.

c) Recycle: Recycling is the effort after the previous two things have already been implemented, where the objects lost their functionality but new products can be created from it. For example, plastic packaging is made into pencil bags or cases, paper waste is recycled, etc. 


\section{METHOD}

The design of this research is qualitative research with case study method. This is because this research focuses on one particular object that studies it as a case. Case study data can be obtained from various sources [10]. Data collection was carried out using observation sheets, in-depth interviews and documentation. This research was conducted since early October 2020 in the city of Banda Aceh, Indonesia. The selected participants were 22 families. Participants come from various educational and professional backgrounds with the hope of finding varied information. Table 1 shows the details of the interviewees.

\section{RESULT AND DISCUSSION}

Based on the results of interviews and observations with several families, the following results were obtained. First, parents' education and background play a major role in implementing the 3R. Majority of parents with higher education backgrounds are more concerned with the problem of solid waste, so they have implemented the 3R at home. Apart from that, parents' knowledge about the environment also affects their lifestyle at home. This is in line with a research concluding that there is a correlation between knowledge of environmental pollution and participation in protecting the environment [11].

Table 1. The Details of Interviewees

\begin{tabular}{|c|c|c|c|c|c|c|c|}
\hline No & $\begin{array}{l}\text { Parent's } \\
\text { name }\end{array}$ & $\begin{array}{l}\text { As Father/ } \\
\text { Mother }\end{array}$ & $\begin{array}{c}\text { Parent's Educational } \\
\text { Background }\end{array}$ & $\begin{array}{l}\text { Parent's } \\
\text { Occupation }\end{array}$ & Child's Name & Child's Age & $\begin{array}{l}\text { Child's } \\
\text { Gender }\end{array}$ \\
\hline 1 & $F$ & Mother & Master degree & Lecturer & AAF & 7 & Male \\
\hline 2 & NR & Mother & Master degree & Lecturer & $A$ & 7 & Male \\
\hline 3 & CPY & Mother & Master degree & Lecturer & CPN & 4 & Female \\
\hline 4 & CRA & Mother & Master degree & Lecturer & I & 3 & Female \\
\hline 5 & $R$ & Mother & Master degree & Housewife & D & 7 & Male \\
\hline 6 & $\mathrm{MRH}$ & Father & Master degree & Lecturer & MRH & 5 & Female \\
\hline 7 & $N$ & Mother & Master degree & Civil Servant & $A$ & 5 & Female \\
\hline 8 & $\mathrm{JH}$ & Father & Master degree & Lecturer & MRAF & 4 & Male \\
\hline 9 & ZDM & Mother & Master degree & Lecturer & GA & 7 & Female \\
\hline 10 & $\mathrm{RH}$ & Mother & Master degree & Lecturer & DAM & 2 & Female \\
\hline 11 & $N$ & Father & Undergraduate & $\begin{array}{l}\text { Private Company } \\
\text { Employee }\end{array}$ & MR & 6 & Male \\
\hline 12 & NF & Mother & Master degree & Lecturer & SAZ & 7 & Male \\
\hline 13 & NA & Mother & Master degree & Lecturer & A & 2,5 & Female \\
\hline 14 & $D$ & Mother & Master degree & Civil Servant & $F$ & 3,5 & Female \\
\hline 15 & $\mathrm{~K}$ & Mother & Undergraduate & $\begin{array}{l}\text { Private Company } \\
\text { Employee }\end{array}$ & RIP & 7 & Female \\
\hline 16 & NA & Mother & Master degree & Housewife & MIAF & 6 & Male \\
\hline 17 & FM & Mother & Master degree & Civil Servant & $\mathrm{N}$ & 7 & Female \\
\hline 18 & RU & Mother & Undergraduate & Teacher & MDA & 7 & Male \\
\hline 19 & $R$ & Father & Master degree & Lecturer & MRMR & 7 & Male \\
\hline 20 & $\mathrm{HA}$ & Father & Master degree & Lecturer & $\mathrm{MH}$ & 5 & Male \\
\hline 21 & FS & Mother & Undergraduate & Housewife & $Y Z$ & 7 & Female \\
\hline 22 & AW & Mother & - & Housewife & L & 5 & Male \\
\hline
\end{tabular}


Second, half of the participants have engaged children in implementing the $3 \mathrm{R}$, which is intended to become a good habit for children. According to the parents, the implementation of $3 \mathrm{R}$ makes children live healthy, familiarizes children to conserve natural resources, forms children to be responsible for nature, and fosters a love for the environment. In addition, this also aims to make children understand the meaning of being efficient, reduce the purchase of unnecessary items because they can be replaced with recycled items, and even foster children's creativity because in the $3 R$ process children are induced to suggest ideas how they can reuse items for different uses. In other words, the application of $3 \mathrm{R}$ has a very close relationship with the development of children's naturalistic intelligence because in the process children gain an understanding of the importance of protecting the environment.

Third, parents introduce $3 \mathrm{R}$ to children by giving direct examples in everyday life such as separating garbage according to its characteristics, bring their own shopping bags, bring their own drinks and food from home, choose containers that can be used repeatedly, and making toys with used bottles and cardboard or anything that can be reused. As we know, children learn through the experience (habituation) they get and imitate what they see.

Fourth, the response of the child after being accustomed to doing the $3 \mathrm{R}$ at home is that the child becomes more concerned about the environment, does not litter, cites the trash he finds on the street or even reminds other people who litter or if garbage is disposed not according to its classification. Some children were found to be more interested in playing with used items than bought toys.

Fifth, the obstacles for some parents in implementing the $3 \mathrm{R}$ at home are the lack of infrastructure for waste management around the neighbourhood (no separated bin for different waste characteristics), implementing $3 R$ is considered troublesome and less hygienic, and the lack of understanding of other family members about the $3 \mathrm{R}$ concept.

\section{CONCLUSION}

There are several conclusions and suggestions that can be drawn as follows:

a) Government needs to be more concerned both in facilitating $3 \mathrm{R}$, especially in waste management, and raising more awareness and education about $3 \mathrm{R}$ for the public.

b) There is a need to develop a well-structured model or method in applying the $3 \mathrm{R}$ to early childhood.

c) It is interesting to follow up this study i.e. by investigating $3 \mathrm{R}$ implementation using quantitative design.

\section{REFERENCES}

[1] M. Tanaka, 2008, Efforts to Reduce SW - Why SW is Generated, How SW is reduced?, Proceeding of International Symposium on SWAPI, KSWM, Incheon, South korea, Nov 12-14 2004, in: E. Damanhuri \& T. Padmi, Pengelolaan Sampah Terpadu, 2019.

[2] H. K. Ma, C. Chiang, The Recycling Scheme of Electronic Waste in Taiwan, Proceeding of International Symposium on SWAPI, KSWM, Incheon, South Korea, Nov 12-14 2008, in E. Damanhuri \& T. Padmi, Pengelolaan Sampah Terpadu, 2019.

[3] E. Damanhuri, T. Padmi, Pengelolaan Sampah Terpadu, ITB Press, 2019.

[4] P. Hendrawan, Indonesia Hasilkan 625 Juta Liter Sampah Sehari. 2012, Retrieved from Tempo.co: https://nasional.tempo.co/read/397147/indonesiahasilkan-625-juta-liter-sampah-sehari,

[5] E. J. Ju, J. G. Kim, Using Soil Seed Banks for Ecological Education In Primary School, Journal of Biological Education, 45(2), 2011, pp. 93-101.

[6] M. Slarp, How ecoliterate is a five year old? Investigating the effects of teaching intervention on kindergarten children's understanding of ecological concepts, The University of Sydney, 2014.

[7] T. Armstrong, Kecerdasan Multiple di Dalam Kelas, Indeks, 2013.

[8] S.D. Gunarsa, Dasar dan Teori Perkembangan Anak,Kencana, 2010.

[9] L. R. Frascaroli, How to apply the $3 \mathrm{R}$ in our home, 2020, Retrieved from Econews Today: https://econewstoday.com/en/uncategorized/howto-apply-the-3r-in-our-home.html

[10] H. Nawawi, Metode Penelitian Bidang Sosial, Gajah Mada University Press, 2003.

[11] D. Yudiana, I.K. Devi, Studi Korelasional Antara Pengetahuan Pencemaran Lingkungan Dan Kecerdasan Naturalis Dengan Partisipasi Ibu Rumah Tangga Dalam Melindungi Lingkungan, Jurnal Pendidikan Lingkungan Hidup, Vol 6 No 1, 2018. 